\title{
Analysis of English Students' Learning Style in Bilingual Class
}

\author{
Andi Asrifan \\ English Education Department, the institute of teachers training and education of Muhammadiyah Rappang, Sidenreng Rappang Regency, \\ South Sulawesi, Indonesia
}

Email address:

andiasrifan@yahoo.co.id

\section{To cite this article:}

Andi Asrifan. Analysis of English Students' Learning Style in Bilingual Class. International Journal of Literature and Arts.

Vol. 3, No. 4, 2015, pp. 34-41. doi: 10.11648/j.ijla.20150304.11

\begin{abstract}
Learning style is the way someone feel easy, comfort and save when they are learning. This research aimed at finding out (i) kinds of learning style, (ii) the most dominant learning style in bilingual class, (iii) factors that influence student learning style, and (iv) the effect of learning style on the students' language achievement. This research was conducted using descriptive qualitative method involving 20 students of SMA Negeri 5 Parepare as participant. The instruments used for this study are questionnaire to identify kinds of learning style and the dominant learning style; interview and observation to identify factors influence student learning style; and written test to identify language achievement. The findings indicated that (i) students learning style in bilingual class divided into three models: modality comprises visual, auditory, and kinesthetic; personality comprises extrovert and introvert; and receiving information comprises global and analytical. (ii) The most dominant learning style in bilingual class is extrovert. (iii) Factors influence students learning style are environment, emotional, sociological, psychological, and teachers. (iv) the effect of learning style on the students language achievement, no significant effect among reading and grammar test, but vocabulary test has.
\end{abstract}

Keywords: Students' Learning Style, Bilingual Education, Bilingual Class

\section{Introduction}

There are many efforts to improve the quality of education especially of English language such as, preparing the facility and infrastructure, revising the curriculum, training for the teacher, developing the material. Right now there is new way or effort to improve the quality of English that is bilingual program. It has the objectives to produce graduates who have high competence in several subjects and master English. Bilingual program has become breakthrough, encouraging the use of English in non English subjects.

However, bilingual class as facility in acquiring the second language and EFL, many things should be done to run this program. Learning in the classroom can occur as a combination of students' personal effort to study about the material which is the teacher attempts to present the material and does interaction with the student. Even though most teachers are not aware of the ways their students prefer to learn the language, or even they are, they pay little attention of them. Most teachers believe students come to the language classroom with different interests and preferences; they are still reluctant to consult learners in conducting language learning activities, hence being unable to meet the learning needs of individual students (Larkin, 2003).

Teachers, therefore, need to discover their students preferred way of learning the language. In the process of the learning language, there are many variables that determine the success of a language learner. Language learning success is associated with a range of factors including age, gender, motivation, intelligence, anxiety level, learning strategies and the last is learning style. As Willis (2008: 15) stated that the more your child knows about the way she learns best, the more insight, strategies, and self-awareness she will have to use her learning strengths to achieve her greatest potential as a joyful learner.

\section{Review of Related Literature}

\subsection{Learning Style}

\subsubsection{Definition of Learning Style}

Husain (2011: 33) states that learning styles describe a students in terms of those educational conditions under which 
he/she is most likely to learn. Meanwhile, Brown (2000: 114) states that when cognitive styles are specifically related to an educational context, where affective and psychological factors are intermingled they are usually referred to as learning style. Dornyei (2005: 134) states learning style is the concept represents a profile of individual's approach to learning, a blueprint of the habitual or preferred way of he individual perceives, interacts with and responds to the learning environment. While Field (2005: 169) states that learning style is an approach to the learning determined by the personality or the cognitive bias of the learners.

Students have different characteristic strengths and preferences in the ways they take in and process information. Their learning styles will be influenced by their genetic make-up, their previous learning experiences, their culture and the society they live in. Some students may focus on facts and data; others are more comfortable with theories and mathematical models. Some respond strongly to visual forms of information, like pictures, diagrams, and schematics; others get more from verbal forms like written and spoken explanations. Some prefer to learn actively and interactively; others function more introspectively and individually (Felder, 1996).

\subsubsection{Models of Learning Styles}

\section{(i). Kolb's Model}

Kolb's learning style (Dornyei, 2005:129) construct is based on the permutation of two main dimension, concrete vs abstract thinking and active vs reflective information processing, that were combined to form four basic learning style:

a) Divergers (concrete \& reflective)

Divergers prefer concrete situations that call for the generation of ideas, such as a brainstorming session.

b) Convergers (abstract and active)

Convergers are abstract thinkers who generate ideas and theories.

c) Assimilators (abstract \& reflective)

Assimilators are also abstract thinkers; they are assimilating disparate observations in a reflective manner.

d) Accommodators (concrete \& active)

Accommodators like concrete experience and active experimentation, and they are stimulated by challenging experiences even to the extent of taking risks.

\section{(ii). Myers-Briggs Type Indicator}

\section{a) Extraversion/Introversion}

Extroverts get recharged by being around people. They are action-oriented. Introverts can be sociable, but need to recharge by having quiet reflective time in their inner world of abstract thinking, conceptualization, and brainstorming ideas.

b) Sensing/Intuition

Sensing learners rely on factual information. They are detail oriented and prefer linear, organized, and structured lectures. Intuitive students rely on their sixth sense of intuition in order to receive and integrate information into a "big picture."

\section{c) Thinking/Feeling}

Thinking learners process information logically and through analysis. They value justice. Feeling students rely on human values to make decisions. They value harmony and tend to be great negotiators and persuaders.

d) Judging/Perceptive

Decisive, self-disciplined learners, who plan things out are judging learners. These students are task oriented and committed to deadlines. Perceptive students tend to wait until the last minute to get their assignments in.

\section{(iii). Mc Carthy's Learning Style}

McCarthy in Gunes (2004:28) developed the 4MAT System to help teachers organize their teaching based on differences in the way people learn. McCarthy formed a four- quadrant model includes four major learning styles;

a) Imaginative Learners

Imaginative learners look for personal meaning and draw on values while learning (Verster, 2003).

b) Analytic Learners

Analytic learners perceive information abstractly and process it reflectively.

c) Common Sense Learners

Common Sense learners perceive information abstractly and process it actively.

d) Dynamic Learners

Dynamic learners perceive information concretely and process it actively.

\section{(iv). Dunn and Dunn Learning Style}

Dunn in Gunes (2004:31) defined learning styles as the ways in which each person absorbs and retains information and/or skills. Dunn conducted studies to determine whether there is any relationship between cognitive dimension and students' characteristics that appeared to be more or less responsive to environmental, emotional, sociological, psychological stimuli.

1) Environmental elements

Learning style such as sound, light, temperature, and design affect the learner's way of taking in new and difficult information.

2) Emotional elements

Learning style (motivation, persistence, responsibility, structure) vary between self- motivated learners, who enjoy learning and achieving, and for whom academic learning in conventional classroom is not fulfilling.

3) Sociological elements

Learning style determine how students react to working alone, with an authority, in a pair, on a small team or group, on a large team or group, or in other varied circumstances.

4) The physiological elements

Learning style are food and drink intake, time of day, mobility, and perceptual elements (visual, auditory, tactile, and kinesthetic preferences).

5) Herman Brain Dominance Model

In Haris et al, (2006), Herrmann combined Roger Sperry's research on right/left brain theory and Paul MacLean's model of rational brain, intermediate brain and primitive brain with 
his own observations to create a four quadrant model:

a) Quadrant A

Thinking is factual, analytical, quantitative, logical, rational and critical.

b) Quadrant B

Thinkers are organized, detailed and like things sequential and planned.

c) Quadrant C

Thinkers are the innovators who prefer brainstorming, metaphors, synthesizing, and holistic approaches to problem solving.

d) Quadrant D

Thinkers are often humanitarians who prefer to cooperative learning and group discussion.

\section{(v). Felder Silverman Learning Style Model}

Felder and Silverman distinguish between preferences on four dimensions. First distinguishes between an active and a reflective way of processing information. Second covers sensing versus intuitive learning. Third, visual-verbal dimension differentiates learners who remember best and who get more out of textual representations, regardless of whether they are written or spoken. Fourth, the learners are characterized according to their understanding; sequential learners and global learners.

\subsection{Bilingual Class}

Essen (2008) states the use of a foreign language as the medium of instruction in a subject other than the language itself is the term of bilingual education. Mars (2009) stated that bilingual education is a term which is used to describe a variety of context. Richard \& Schmit, (2002:52) Bilingual education is the use of a second or foreign language in school for the teaching of contents subject.

Bilingual Education program is an education program for children whose native language is not English. Children are taught for some porsion of the day in their native language, with the goal of moving them into mainstream English classes as quickly as possible. Santoso (2006) in his paper argued some of the benefit of bilingual education in Indonesia; bilingual education enables students to use of various strategies to foster their understanding, bilingualism does not mean that the role of the first language is neglected and totally ignored. In learning two languages some fundamental notion should be remembered, they are first language literacy, educational background, English language proficiency level, cultural background, age, learning style, motivation, and larger sociolinguistic and educational context surrounding the school (Field:2009).

Raguanued (2009:109) mentioned some of the benefit of bilingualism; first is academic skill, second is access to more knowledge, third is self esteem, and fourth is a balanced cultural identity.

\section{Methodology}

This researcher employed descriptive qualitative design which aims at describing learning style used by students in learning English in the bilingual classroom. The participant is 20 students from grade X of SMA Negeri 5 Parepare. The data were collected through questionnaire, observation, interview, and achievement test. The data were analyzed through the steps of reading/memoing, describing and classifying.

\section{Findings}

\subsection{Learning Styles in Bilingual Class}

To find out the students' learning style, they were asked to complete the questionnaire.

Table 1. Students Visual Learning Style Preference.

\begin{tabular}{llllll}
\hline Question Item & $\begin{array}{l}\mathbf{N} \\
\mathbf{( \% )}\end{array}$ & $\begin{array}{l}\mathbf{R} \\
\mathbf{( \% )}\end{array}$ & $\begin{array}{l}\mathbf{S} \\
\mathbf{( \% )}\end{array}$ & $\begin{array}{l}\mathbf{O} \\
\mathbf{( \% )}\end{array}$ & $\begin{array}{l}\mathbf{A} \\
\mathbf{( \% )}\end{array}$ \\
\hline $\begin{array}{l}\text { 1. I remember something } \\
\text { better if I write it down }\end{array}$ & 5 & 5 & 55 & 15 & 20 \\
$\begin{array}{l}\text { 2. I take detailed notes during } \\
\text { lectures }\end{array}$ & 5 & 0 & 58 & 21 & 16 \\
$\begin{array}{l}\text { 3. } \begin{array}{l}\text { when I listen I visualize } \\
\text { pictures, members, or } \\
\text { words in my head }\end{array} \\
\begin{array}{l}\text { 4. I prefer learn with TV or } \\
\text { video than other media }\end{array}\end{array}$ & 10 & 10 & 32 & 37 & 11 \\
\hline
\end{tabular}

Table 1 shows that students preferred to remember something better if they write it down and when they listen and students visualize picture, members or words in their heads, or sometimes they take detailed notes during lectures. This learning preference falls under the modality model, in which one of its learner types is visual learner.

Table 2. Students Auditory Learning Style Preference.

\begin{tabular}{llllll}
\hline Question item & $\begin{array}{l}\mathbf{N} \\
\mathbf{( \% )}\end{array}$ & $\begin{array}{l}\mathbf{R} \\
\mathbf{( \% )}\end{array}$ & $\begin{array}{l}\mathbf{S} \\
\mathbf{( \% )}\end{array}$ & $\begin{array}{l}\mathbf{O} \\
\mathbf{( \% )}\end{array}$ & $\begin{array}{l}\mathbf{A} \\
\mathbf{( \% )}\end{array}$ \\
\hline 5. $\begin{array}{l}\text { I prefer to learn by } \\
\text { listening to a lecture rather } \\
\text { than reading }\end{array}$ & - & 5 & 20 & 30 & 45 \\
$\begin{array}{l}\text { 6. } \\
\begin{array}{l}\text { Background sound helps } \\
\text { me think }\end{array}\end{array}$ & 15 & 20 & 30 & 20 & 15 \\
7. $\begin{array}{l}\text { I can understand what } \\
\text { people say even when I } \\
\text { cannot see them }\end{array}$ & 10 & 21 & 37 & 32 & 0 \\
8. $\begin{array}{l}\text { I can identify people by } \\
\text { their voice }\end{array}$ & 0 & 30 & 20 & 35 & 15 \\
\hline
\end{tabular}

Table 2 shows that students preferred to learn by listening to a lecture rather than reading, they also identify people by their voice, and they can understand what people say even they cannot see them. This learning preference falls under modality model, in which of its learner types is auditory learner. 
Table 3. Students Kinesthetic Learning Style Preference.

\begin{tabular}{|c|c|c|c|c|c|}
\hline Question Item & $\begin{array}{l}\mathbf{N} \\
(\%)\end{array}$ & $\begin{array}{l}\mathbf{R} \\
(\%)\end{array}$ & $\begin{array}{l}\mathrm{S} \\
(\%)\end{array}$ & $\begin{array}{l}\mathbf{O} \\
(\%)\end{array}$ & $\begin{array}{l}\text { A } \\
\text { (\%) }\end{array}$ \\
\hline $\begin{array}{l}\text { 9. I need to eat or drink } \\
\text { something when I learn }\end{array}$ & 0 & 35 & 25 & 20 & 20 \\
\hline $\begin{array}{l}\text { 10. If I have a choice } \\
\text { between sitting and } \\
\text { standing, I'd rather } \\
\text { stand }\end{array}$ & 15 & 30 & 50 & 0 & 5 \\
\hline $\begin{array}{l}\text { 11. I get nervous when I sit } \\
\text { still too long }\end{array}$ & 0 & 10 & 35 & 15 & 40 \\
\hline $\begin{array}{l}\text { 12. I think better when I } \\
\text { move around }\end{array}$ & 5 & 5 & 16 & 37 & 37 \\
\hline
\end{tabular}

Table 3 shows that students get nervous when they sit too long, they also think better when they move around, and they would rather stand if they have a choice between sitting or standing. This learning preference falls under mobility model, in which of its learner types is kinesthetic.

Table 4. Students Extrovert Learning Style Preference.

\begin{tabular}{|c|c|c|c|c|c|}
\hline Question Item & $\begin{array}{l}\mathrm{N} \\
(\%) \\
\end{array}$ & $\begin{array}{l}\mathbf{R} \\
(\%) \\
\end{array}$ & $\begin{array}{l}\mathrm{S} \\
(\%) \\
\end{array}$ & $\begin{array}{l}\mathbf{O} \\
(\%) \\
\end{array}$ & $\begin{array}{l}\mathbf{A} \\
(\%)\end{array}$ \\
\hline $\begin{array}{l}\text { 1. I learn better when I work } \\
\text { or study with others than } \\
\text { by myself }\end{array}$ & 0 & 5 & 25 & 40 & 30 \\
\hline $\begin{array}{l}\text { 2. I meet new people easily } \\
\text { by jumping into the } \\
\text { conversation }\end{array}$ & 0 & 5 & 25 & 55 & 15 \\
\hline $\begin{array}{l}\text { 3. It is easy for me to } \\
\text { approach strangers }\end{array}$ & 0 & 15 & 40 & 30 & 15 \\
\hline $\begin{array}{l}\text { 4. Interacting with lots of } \\
\text { people gives me energy }\end{array}$ & 0 & 5 & 30 & 45 & 20 \\
\hline
\end{tabular}

In table 4 , students preferred to make conversation with new people, they get more energy when they interact with lots of people, they also easy to approach the strangers, learn better when they work or study with others. This learning preference falls under personality model, in which of its learner types is extrovert.

Table 5. Students Introvert Learning Style Preference.

\begin{tabular}{llllll}
\hline Question Item & $\begin{array}{l}\mathbf{N} \\
\mathbf{( \% )}\end{array}$ & $\begin{array}{l}\mathbf{R} \\
\mathbf{( \% )}\end{array}$ & $\begin{array}{l}\mathbf{S} \\
\mathbf{( \% )}\end{array}$ & $\begin{array}{l}\mathbf{O} \\
\mathbf{( \% )}\end{array}$ & $\begin{array}{l}\mathbf{A} \\
\mathbf{( \% )}\end{array}$ \\
\hline $\begin{array}{l}\text { 5. Prefer individual } \\
\text { activities }\end{array}$ & 0 & 25 & 50 & 20 & 5 \\
$\begin{array}{l}\text { 6. When I am in a large } \\
\text { group, I tend to keep } \\
\text { silent and listen }\end{array}$ & 5 & 25 & 50 & 5 & 15 \\
$\begin{array}{l}\text { 7. I want to understand } \\
\text { something well before I } \\
\text { try it }\end{array}$ & 0 & 0 & 20 & 30 & 50 \\
$\begin{array}{l}\text { 8. I have few interest, and I } \\
\text { concentrate deeply on } \\
\text { them }\end{array}$ & 0 & 10 & 30 & 40 & 20 \\
\hline
\end{tabular}

In table 5, students preferred to understand something well before try it. They also prefer individual activities than group, they tend to keep silent and listen. This learning preference falls under personality model, w learner types is introvert.
Table 6. Students Global Learning Style Preference.

\begin{tabular}{|c|c|c|c|c|c|}
\hline Question Item & $\begin{array}{l}\mathrm{N} \\
(\%)\end{array}$ & $\begin{array}{l}\mathrm{R} \\
(\%) \\
\end{array}$ & $\begin{array}{l}\mathrm{S} \\
(\%)\end{array}$ & $\begin{array}{l}\mathbf{O} \\
(\%) \\
\end{array}$ & $\begin{array}{l}\text { A } \\
(\%)\end{array}$ \\
\hline $\begin{array}{l}\text { 1. I prefer short and simple } \\
\text { answers rather than long } \\
\text { explanations }\end{array}$ & 0 & 0 & 15 & 30 & 55 \\
\hline $\begin{array}{l}\text { 2. I get the main idea, and } \\
\text { that's enough for me }\end{array}$ & 0 & 5 & 30 & 40 & 25 \\
\hline $\begin{array}{l}\text { 3. When I tell an old story, I } \\
\text { tend to forget lots of } \\
\text { specific details }\end{array}$ & 0 & 5 & 63 & 31 & - \\
\hline $\begin{array}{l}\text { 4. It is easy for me to see the } \\
\text { overall plan or big picture }\end{array}$ & 0 & 5 & 70 & 25 & 0 \\
\hline
\end{tabular}

Table 6 show that students preferred short and simple answer rather than long explanations, they get main idea and that enough for them and they easy to see overall plan or big picture. This learning preference falls under receiving information model, in which of its learner types is global.

Table 7. Students Analytical Learning Style Preference.

\begin{tabular}{|c|c|c|c|c|c|}
\hline Question Item & $\begin{array}{l}\text { N } \\
(\%)\end{array}$ & $\begin{array}{l}\text { R } \\
(\%)\end{array}$ & $\begin{array}{l}\text { S } \\
(\%)\end{array}$ & $\begin{array}{l} \\
(\%)\end{array}$ & $\begin{array}{l}\text { A } \\
(\%)\end{array}$ \\
\hline $\begin{array}{l}\text { 5. I need very specific } \\
\text { examples in order to } \\
\text { understand fully }\end{array}$ & 0 & 5 & 10 & 60 & 25 \\
\hline $\begin{array}{l}\text { 6. I pay attention to } \\
\text { specific facts or } \\
\text { information }\end{array}$ & 0 & 0 & 35 & 45 & 20 \\
\hline $\begin{array}{l}\text { 7. I'm good at catching } \\
\text { new phrases or words } \\
\text { when I hear them }\end{array}$ & 0 & 25 & 35 & 35 & 5 \\
\hline $\begin{array}{l}\text { 8. When I try to tell a joke, } \\
\text { I remember details but } \\
\text { forget the punch line }\end{array}$ & 0 & 10 & 58 & 21 & 11 \\
\hline
\end{tabular}

Based on table 7, students preferred to remember detail but forget the punch line in tell the joke, they need very specific examples in order to understand fully. This learning preference falls under receiving information model, in which of its learner type is analytical.

From the result of the questionnaire, it is found that the most dominant learning style used by the students is extrovert. It could be presented in the figure below

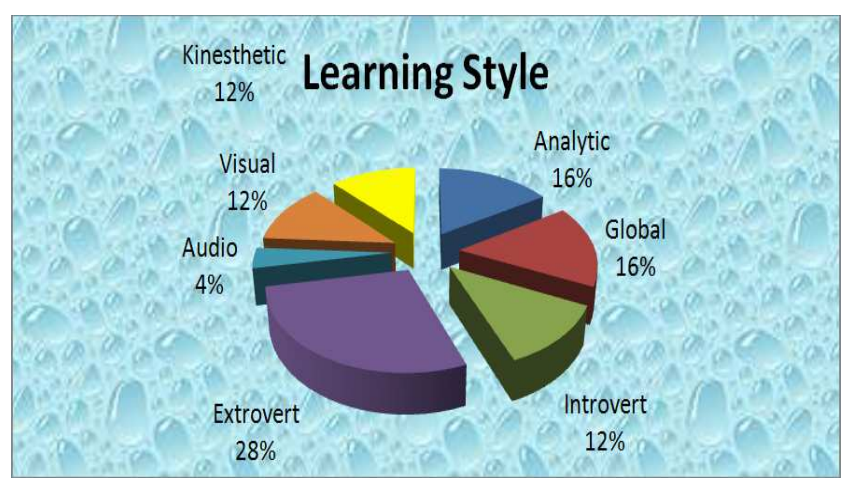

Figure 1. The Percentage of Learning Style.

The data were also supported from the result of the seven students' interview who are extrovert learning style learners:

WA: I like disturbing my friends, mock and I love join in 
the new situation or new friend. I love singing, dancing and laughing. If we just became quiet we don't have friend.

NS: In the new environment I'm quick in socialization, when I met with new people I will say hello first to them and in class I'm so talkative.

LP: In new place I can socialize well, but I prefer serious situation, if I get stress I directly love crowded place. I feel comfort if I join with overacting people.

MF: I'm a simple person, selfish and impatient person. Easy socialize in new environment

AA: I'm sociable, noisy, and selfish but I care, sensitive with people around me, it's easy to socialize in new environment

MI: I can act based on the situation, it means when the situation crowded I will also involve it and when the situation is silence so I do like that. I'm also easy to socialization with new person or environment.

MIK: I prefer socialize with my senior in school, with mature mind. I like in the crowded place, but not too crowded, I like laughing and make joking

\subsection{Factors Influence Students Learning Style in Bilingual Class}

From the interview it was found that many factors influence students learning style in Bilingual class, such as environment, mood (emotional), teachers' method, sociological, and psyiology. It can be seen in table 8 .

Table 8. Factors Influence Students Learning Style.

\begin{tabular}{lll}
\hline No & Factors Influence & Elements \\
\hline 1 & Environment & Sound \\
2 & Emotional & Temperature \\
3 & Teachers & Teaching method / strategy in teaching \\
4 & Sociologial & Alone \\
5 & Psyiology & Peer/group \\
\hline
\end{tabular}

Environment factor has two elements; sound and temperature, sound element here noisy and quiet, some students prefer to learn in noisy situation and some prefer in quiet situation, as the result of interview:

WA: Since I was in Senior, because the situation here. It's quite, so I think if I learn with that way it's easy to understand. When in junior I didn't do that, but speak louder it from the past.

MIK : since in here, I'm lazy boy since I was in junior.

The data shows students really affected with sound when they learning. The data also answer the question 'since when you did your learning style?" Second element in environment factor is temperature as the data show:

AA: I like learning alone, which the temperature is not quite hot or cold, average and there should be music.

The data shows temperature also become factors influence students learning style, because some students can't concentrate when the temperature are too warm or too cold.

Second factor influence students learning style is mood (emotional);
MF: Silence and crowded, I mean it depends on the mood. When I get a good mood it doesn't matter with the situation, but when I'm in bad mood I need a silence place to learn.

Logically, positive mood can trigger someone become more motivated or excited involved in the learning process, prepare himself/herself, and to deal with the academic performance evolution.

Third factor influence students learning style is teachers' method in teaching.

MF: It depends on the teacher method, when they have a good method, I prefer learning in class but when we learn in outside of the class sometime the teacher voice is unclear.

From the data above, it is necessary for teacher to know kind of method in teaching they should use.

Next factor influence students learning style is sociological; whether students like studying alone or with their peer.

WA: I learn first, after I get obstacle I will ask someone

NS: Directly ask to someone, or if I get stuck I ask and I always do that.

Both data explain about sociological factor affect students learning style. And last factor is physiological here related with the best time students like to learn:

NS: After isha prayer, if there is no short course in the evening. It's about 1 hour, or I spend the night if I have exam or I have many tasks

MF: In the noon I prefer learn with music but in the night should be quite

The data above is the answer of the question 'what time do you always study'? Time also influence students learning style, some students prefer learn in the night, the other prefer in the noon.

\subsection{Students Achievement in Learning Language Based on Their Learning Style}

To gain the data, the writer gave the students vocabulary, reading and grammar test in the form of written test. We can see the result of the data in figures below:

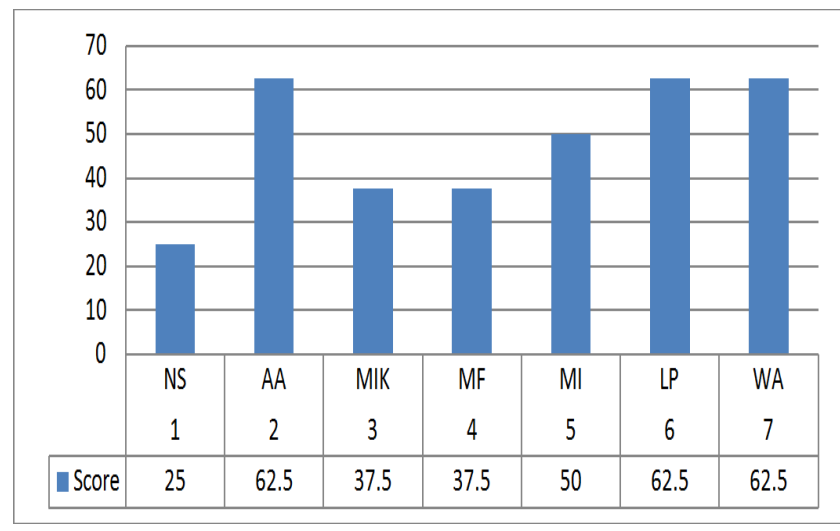

Figure 2. Reading Test Score.

As the figure 2 shown 3 persons got 62.5 score which is became the first rank, followed by 50 score, next was 37.5 two participants, and last score was 25 with one participant. 


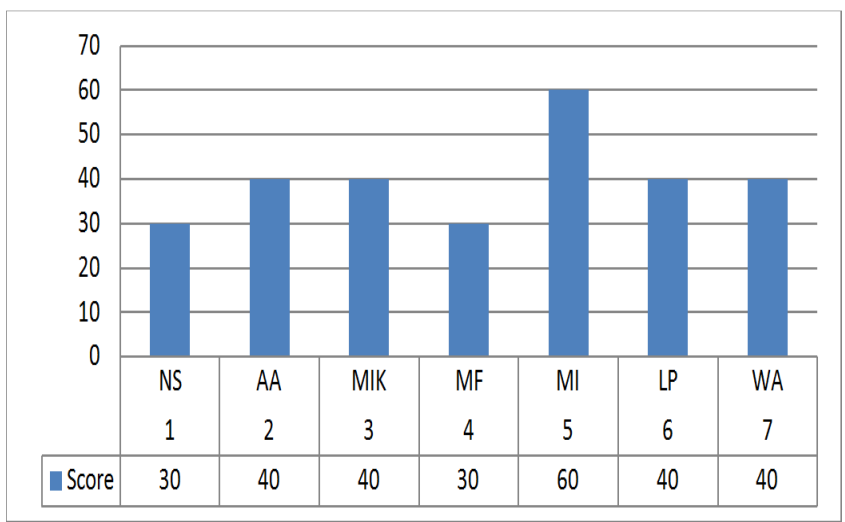

Figure 3. Grammar Test Score.

The figure 3 shows that from the grammar test, the highest score was 60 with one participant, followed score 40 with 4 participants and score 30 with 2 participants.

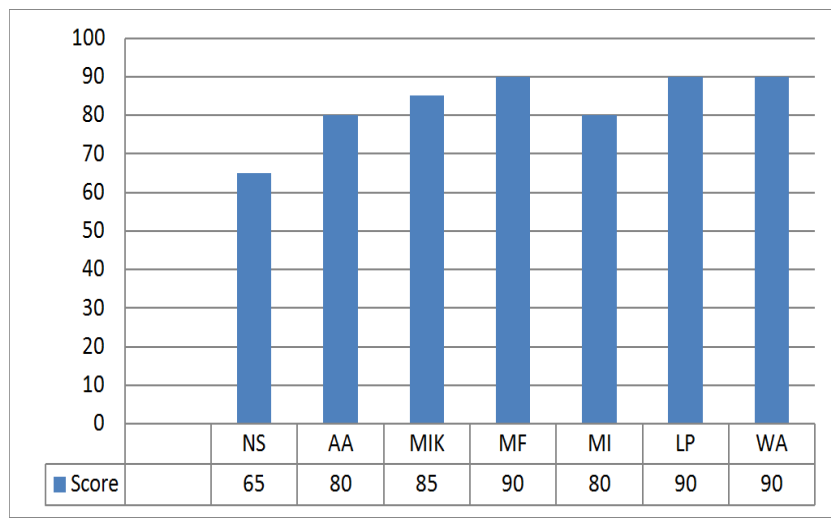

Figure 4. Vocabulary Test Score.

The figure 4 shows that from the vocabulary test, the highest score was 90 with 3 persons, followed 85 score with 1 person, score 80 with 2 persons and 65 score with 1 person.

\section{Discussion}

\subsection{Learning Style in Bilingual Class}

The finding showed that majority students in this class prefered with extrovert learning style; there are seven students who have this learning style. As we can see most of the students' love gathering with their friend, make some noisy, talk each other, working with group or discuss with their friend. However, these kinds of learning style have got interaction from other function, it means that the dominant factor (extrovert) in their application always get help from other function (other learning style), it completes the dominant learning style.

As we know that extrovert learning style characteristics are talkative, open show emotions act before thinking, like to be with people. An extrovert learner is generating energy and ideas from other people. They prefer socializing and working in groups. Learning activities that benefit extrovert learners include teaching others how to solve problem, collaborative/group work, and problem-based learning.
Learning style generally operates in multiple, for example, some students could be more extrovert or introvert, or more global than analytical, or equally visual and audio with less kinesthetic. As we can see from my participants, WA learning style is extrovert, less with analytical, NS has equal learning style among kinesthetic and extrovert, LP also has equally learning styles; visual, extrovert and analytical, MF; is extrovert, with less visual, AA; is extrovert with less analytical, MI is extrovert with less global and MIK has equally extrovert and global.

\subsection{Factors Influence Students Learning Style in Bilingual Class}

Based on the data in findings there are six factors influence students learning style in class, first is environment. In this case environment factors divided with two; sound and temperature.

Beside that, the factors that influence students learning style; mood (emotional), logically, positive mood can trigger someone become more motivated or excited involved in the learning process, prepare himself/herself, and to deal with the academic performance evolution. It is related with the data above, the participant feel free to learn in all kinds condition if he feels good mood, and when he feels bad mood he need a silence place to learn. Killen (2004) stated learners enter the classroom with the feeling and emotions that result from how they see themselves and how they think others see them. These emotional factors play a big part in determining which learners feel a sense of "belonging" in the learning environment and which learner fell alienated.

Not only students factors but teacher factor also affect students learning style, in this case teacher strategy or method in teaching. The teacher should know about students learning style, so they can match students learning style and their teaching method, as Salma Kera (2009) stated in her research 'learners said that they feel unhappy and frustrated when their teachers do not teach in their favored style. Teachers said that when they become aware of a mismatch, they change the presentation or type of activity. However, at the beginning of the semester, the teachers do not take learning styles into consideration. Gilakjani and Ahmadi (2011) stated in order to achieve goal of students learning, it is important to use a combination of teaching methods and to make classroom environment as stimulating and interactive as possible.

Next factor is sociological; whether students like studying alone or with their peer. And last factor is physiological here related with the best time students like to learn, the data above is the answer of the question 'what time do you always study'? Time also influence students learning style, some students prefer learn in the night, the other prefer in the noon.

\subsection{Students Language Achievement Based on Learning Style}

Sadeqhi, et all, (2012) stated that the relationship between personality and success in reading comprehension - are not 
congruent. We can see also from the data that more extrovert learners tended to have lowest score in reading comprehension. Based on the previous research and the data from this research, there was no effect of learning style in this case extrovert learning style and students language achievement, especially in reading comprehension.

Kafipour, et. All (2011) learning style of the learner didn't contribute to their vocabulary level. It contradicted with the data that observer found that extrovert affect student language achievement. Busch in Naveh, et all (2011) explored the relationship between introversion-extraversion and English language proficiency of 105 adult school and 80 junior college learners in Japan. A Japanese version of EPI and a nationally standardized English test, consisting grammar/vocabulary, reading, aural comprehension and dictation were used to collect data. In general, no significant relationships were found between extraversion and language measures. Moreover, extraversion was almost correlated significantly and negatively with the components of grammar/vocabulary and reading comprehension.

As Yan Zang (2008) found that extrovert acquire second language learner better than introvert. It contradicted with the data found in this class, students learning style (extrovert) didn't affect their achievement, and also the extrovert students didn't acquire second language better, exception for vocabulary.

\section{Conclusion}

In summary, this study showed that students' learning style in bilingual class vary widely. Visual, auditory, kinesthetics, global, analytical, introvert and extrovert are involved in it. However, the students' dominant style is extrovert.

Furthermore, there were some factors that influence students learning style in bilingual class such as; environment, emotional, teachers, sociological and psychological.

The last part of this study tried to find the effect of learning style on the student language achievement. The result revealed that there was no effect between learning style and student language achievement especially in reading and grammar, but in vocabulary, the observer found that learning style effect students' vocabulary achievement.

\section{Suggestion}

It suggested that the next researcher study deeply about the relation between learning style and learning achievement, and the factors that influence students learning style because by knowing all the factors; it might help the teacher to set their material and method in teaching in the class, so the quality of education might improve.

\section{Acknowledgements}

This research was supported by The Higher Education Directorate of Indonesia and Sekolah Tinggi Keguruan dan Ilmu Pendidikan (STKIP) Muhammadiyah Rappang,
Indonesia. The researcher thank his mentors from Prof. Dr. Baso Jabu, M.Hum (State University of Makassar), Samtidar, S.Pd.,M.Ed.,Ed.D.,Ph.D (State University of Makassaar), Dr. Sarifuddin Dolla, M.Pd. (State University of Makassar), Dr. Sukardi Weda, SS.,S.Pd.,M.Pd.,M.Si.,M.Hum.,MM.,M.Sos.I (State University of Makassar), and Prof. Dr. Haryanto, M.Pd. (State University of Makassar) who provided insight and expertise that greatly assisted the research.

\section{References}

[1] Brown, Douglas H. (2000). Principles of Language Learning and Teaching. New York: A Pearson Education Company.

[2] Dornyei, Zoltan. 2003. The Psychology of the Language Learner Individual Differences in Second Language Acquisition. Lawrence Erlbaum Associates Publisher. New Jersey.

[3] Essen, Van Arthur. 2008. Language Teacher Training and Bilingual Education in the Netherland. University of Groningen. Retrieved May 21, 2012 from www. userpage.fuberlin.de/elc/.../SP6NatRepNL.do...

[4] Esfandabad, Hassan S \& Emamipour. 2010. A comparative study of learning styles among monolingual (Persian) and Bilingual (Turkish-Persian) Secondary School Students. Journal of Procedia Social and Behaviour Sciences 5, Retrieved May 5, 2012 from www.sciencedirect.com

[5] Felder, Richard. (1996). Matters of Style. ASEE Prism, 6 (4), 18-23. Retrieved March 28, 2012 from www.ncsu.edu/felderpublic/Papers/LS-Prism.html

[6] Field, John. 2005. Pshycolinguistics The Key Concept. Taylor \& Franchis E-Library.

[7] Gilakjani, Abbas P \& Ahmadi, Sayedeh M (2011). The effect of visual, auditory and kinaesthetic Learning style on Language Teaching. Paper presents in 2011 International Conference on Social Science and Humanity. Singapore. Retrieved January 10, 2012 from www.ipedr.com/vol.5/no2/104-H10249.pdf

[8] Gunes, Cevriye. 2004. Learning Styles Preferences of Prepatory School Students at Gazi University. Unpublished Thesis. The Department of Educational Sciences. Middle East Technical University.

[9] Harris, L.V, et al. 2006. A Comparison of Learning Style Models and Assessment Instrument for University Graphics Educators. Engineering Design Graphics Journal, Vol 70, No 1 (2006). Retrieved May 5, 2012 from http://www.edgj.org/index.php/EDGJ/article/view/44

[10] Husain, Djamiah. 2011. Fostering Autonomos Learning Inside and Outside The Classroom in Language Learning. Badan Penerbit UNM.

[11] Kara, Selma, 2009. Learning Style and Teaching Style; A Case Study in Foreign Classroom. 23/1/2012, Conference of the International Journal of Arts and Sciences. Anadolu University, Turkey. Retrieved November 26, 2011 from www.openacceslibrary.org,

[12] Mars, David, et al. 2009. Language Teacher Training and Bilingual Education in Finland. Retrieved March 16, 2012 
from www.userpage.fu-berlin.de/elc/.../SP6NatRepFI.pdf

[13] Raguenaud, Virginia. 2009. Bilingual by Choice Raising Kids in Two (or more) Langugaes. Nicholas Brealey Publishing. Boston

[14] Richard, Jack C, et al. 2002. Longman Dictionary of Language Teaching and Applied Linguistic. Pearson Education Limited. London

[15] Santoso, Teguh. 2006. The Benefit of Bilingual Education and its Applications in Indonesia. Jurnal Pendidikan Penabur. No.06/Th.V/Juni. Retrieved April 21, 2012 from www.bpkpenabur.or.id
[16] Teresa L Larkin, 2003. Learning style in the classroom: a research-guided approach. International conference on engineering and computer education. March 16-19, 2003. Sao Paolo, Brazil. Retrieved April 9, 2012 from academic2.american.edu/ tlarkin/pdf files/LarkinICECE2003 .$P D F$

[17] Verster, Cheron. (2003). Learning Styles and Teaching. Retrieved April 9, 2012 fromhttp://www.teachingenglish.org.uk/think/met hodology/learningstyle.sht

[18] Willis, MD, Judy. 2008. How Your Child Learns Best. Sourcebooks. Inc. Naperville, Illinois. 